\title{
MODELING OF ASYMPTOTICALLY OPTIMAL PIECEWISE LINEAR INTERPOLATION OF PLANE PARAMETRIC CURVES
}

Frolov O. V. - PhD, Associate Professor, Associate Professor at the Information Systems Department, Simon Kuznets Kharkiv National University Of Economic, Kharkiv, Ukraine.

Losev M. U. - PhD, Associate Professor, Associate Professor at the Information Systems Department, Simon Kuznets Kharkiv National University Of Economic, Kharkiv, Ukraine.

\section{ABSTRACT}

Context. Piecewise linear approximation of curves has a large number of applications in computer algorithms, as the reconstruction of objects of complex shapes on monitors, CNC machines and 3D printers. In many cases, it is required to have the smallest number of segments for a given accuracy.

Objective. The objective of this paper is to improve the method of asymptotically optimal piecewise linear interpolation of plane parametric curves. This improvement is based to research influence of the method parameters and algorithms to distributions of approximation errors.

Method. An asymptotically optimal method of curves interpolation is satisfied to the condition of minimum number of approximation units. Algorithms for obtaining the values of the sequence of approximation nodes are suggested. This algorithm is based on numerical integration of the nodes regulator function with linear and spline interpolation of its values. The method of estimating the results of the curve approximation based on statistical processing of line segments sequence of relative errors is substantiated. Modeling of real curves approximation is carried out and influence of the sampling degree of integral function - the nodes regulator on distribution parameters of errors is studied. The influence is depending on a method of integral function interpolation.

Results. Research allows to define necessary the number of discretization nodes of the integral function in practical applications. There have been established that with enough sampling points the variance of the error's distribution stabilizes and further increasing this number does not significantly increase the accuracy of the curve approximation. In the case of spline interpolation of the integral function, the values of the distribution parameters stabilized much faster, which allows to reduce the number of initial sampling nodes by 5-6 times having similar accuracy.

Conclusions. Modelling of convex planar parametric curves reconstruction by an asymptotically optimal linear interpolation algorithm showed acceptable results without exceeding the maximum errors limit in cases of a sufficient discretization of the integral function. The prospect of further research is to reduce the computational complexity when calculating the values of the integral distribution function by numerical methods, and to use discrete analogues of derivatives in the expression of this function.

KEYWORDS: interpolation, polyline segment, linear rational B-spline, equidistant, integration, parametric curve, approximation error, variance.

\begin{abstract}
ABBREVIATIONS
3D is a three-dimensional form;

LRBS is a linear rational B-spline;

$\mathrm{CNC}$ is a computer numerical control.
\end{abstract}

\section{NOMENCLATURE}

$\varepsilon$ is an admissible interpolation error bound, which corresponds to the Hausdorff distance between the curve and the polyline;

$[a]$ is an integer part of $a$;

$d_{j}$ is a Hausdorff distance between the curve and the $j$ th segment of the polyline;

$h$ is a sampling step;

$i, j$ are indexes;

$l_{j}$ is a segment of the interpolant polyline;

$m$ is a number of polyline segments;

$N$ is a number of points for initial sampling of the integral function - the nodes regulator;

$\mathbf{p}$ is a vector-valued function of parameter (independent variable) $t$;

$\mathrm{P}$ is a point on the curve;

$t$ is a parameter (independent variable) varies over the interval $[0, T]$;

$s$ is a reparameterization parameter that determines the asymptotically optimal sampling of the curve;

(C) Frolov O. V., Losev M. U., 2021

DOI 10.15588/1607-3274-2021-3-6 $w_{i}$ are weights of the linear rational B-spline;

$x, y$ are Cartesian coordinates;

$\gamma_{j}=d_{j}^{\max } / \varepsilon$ is a relative interpolation error for $j$-th segment of the polyline;

$\Delta$ is an interpolation error of the integral function;

$\lambda_{i, i+1}$ is a value between 0 and 1 , which determines the value of the curve parameter $t_{i+1 / 2}$ within the LRBspline interpolation interval;

$\sigma$ is a standard deviation for the sample;

$\bar{\theta}$ is a sample mean;

$\Gamma$ is a plane curve;

$\Delta$ is a range of error values for the polyline segments sequence;

$\Phi(t)$ is a nodes distribution function;

$\Psi(t)$ is an integral of the distribution function which define asymptotically optimal sampling of interpolation nodes.

\section{INTRODUCTION}

A wide range of applications requires a transition from "curvilinear" representation of objects to their description in the form of polygons or segments of poylines. These 
are rendering, tessellation, finding the intersections of curves and surfaces. Most $\mathrm{CNC}$ machines and 3D printers also support only a limited set of interpolation commands, the most common of which are linear, circular, and helical.

Therefore, the reconstruction of continuous geometric objects, such as curves and surfaces, using computers, $\mathrm{CNC}$ machines or printers requires sampling: representation as a finite set of points (nodes). This set is then converted to pixels or connected by simpler lines (usually straight lines). Of course, there is a problem of optimizing the nodes number and their location along the curve or surface being reconstructed.

Thus, the development of effective algorithms for reconstructing curves by polylines, considering the accuracy of approximation and optimization of segments number is an actual scientific problem.

The object of study is polylines that reconstruct the given convex plane curves and are formed from the nodes that are on these curves.

The subject of study is the asymptotically optimal piecewise linear interpolation of convex plane curves that ensuring a required approximation error bound.

The aim of the work is to improve the method of asymptotically optimal piecewise - linear interpolation of convex plane parametric curves based on research of influence of parameters and algorithms of this method on approximation errors distributions for real curves.

\section{PROBLEM STATEMENT}

Let a reconstructing curve is represented in the vector - valued parametric form as a single arc:

$$
\mathbf{p}=\mathbf{p}(t)(x=x(t), y=y(t)),
$$

or a piecewise parametric form, for example the spline form:

$$
S(t)=\sum_{j=1}^{k} a_{j} B_{j}(t)
$$

In this case, the problem of linear interpolation of the curve can be considered as obtaining a sequence of values of the parameter $t$, which determine the polyline nodes, and provides the required accuracy of reproduction.

Asymptotically optimal in the Hausdorff metric [1] is the polyline interpolation of a plane curve, based on the following choice of nodes:

1) The number of polyline segments can be determined according to the formula:

$$
m=\left[\frac{1}{\sqrt{8 \varepsilon}} \int_{0}^{T} \Phi(t) d t\right]+1
$$

where the distribution function has following form:

$$
\Phi(t)=\sqrt{\frac{\left|x^{\prime \prime}(t) y^{\prime}(t)-x^{\prime}(t) y^{\prime \prime}(t)\right|}{\sqrt{x^{\prime}(t)^{2}+y^{\prime}(t)^{2}}}} .
$$

1) The $j$-th value of the parameter $-t_{j}$, which define the interpolation node for the curve without the inflection points (for $\Phi(t) \neq 0, t \in[0, T]$ ), is obtained from the equation:

$$
\int_{0}^{t_{j}} \Phi(t) d t=\frac{j}{m} \int_{0}^{T} \Phi(t) d t,(j=0,1, \ldots, m) .
$$

Since the right-hand side of the equation (5) is a monotonic increasing discrete sequence, in the limiting case this sequence can be considered as a variable $s$, and expression (5) as an equation of reparameterization.

Let define

$$
\Psi(t)=\int_{0}^{t} \Phi(u) d u
$$

the dependence between the parameters will take the form

$$
t=\Psi^{-1}(s)
$$

where $\Psi^{-1}$ is the inverse function of $\Psi$.

It is possible to obtain the single value of $t$ only when $\Psi$ is a monotone increasing function. In addition, most often the integral of the right-hand side of (6) has no finite expression. This leads to sample the values of the integral function based on the numerical integration of the righthand side (6).

\section{REVIEW OF THE LITERATURE}

Numerous studies are related to the development of algorithms for piecewise linear reconstruction of curves. These studies include the papers focused on interpolation of curves when the polyline nodes are on the original curve, and studies on the approximation of curves, which will mean the location of these nodes and the polyline itself within the "tolerance", which is determined by the accuracy of reproduction.

Non-uniform interpolation that adapts to the shape of the curve was considered in [2]. Usually the following procedure is performed: the original ordered set of curve points obtained by the initial uniform sampling is taken; the original set is divided into intervals; for each interval, the internal nodes are checked according to the criteria of local flatness; depending on the result of the check interval is divided into two parts and followed by recursive check, or the end points of the interval are stored in a separate list of nodes that meet the flatness criterion.

The sampling of curve points based on reparameterization depending on the curvature and mixed parameterization of the arc length and curvature with equal weights was considered in [3]. A similar approach to the sampling 
is considered in [4], where the mixed criteria was taken as the length of the arc and the bending energy of the curve (which depends on the square of the curvature). These methods $[3,4]$ require numerical integration and solving the system of nonlinear equations.

A review and analysis of real time linear interpolators for parametric curves applied to use in of $\mathrm{CNC}$ systems is given in [5]. The use of a conical cutting tool for $\mathrm{CNC}$ machining of free - form surfaces is also required piecewise linear representation of curves - [6]. The reconstruction of the curve by polygon segments in relation to the printing of models on 3D printers was considered in [7].

The issue of reconstruction of a plane curve by a discrete set of points with noise was considered in [8]. The approach to solving the problem is based on the least squares method and minimization of the function, which contains a given set of points and angular coefficients of the polyline segments, using the linear programming methods.

In [9], the method of particle swarm optimization was used to construct a piecewise linear approximation of parametric curves.

The question of the best piecewise - linear approximation to the plane curve without inflection points $y=f(x)$ with polyline nodes that do not lie on the curve, and examples of such approximation were considered in [10]. Optimal piecewise linear approximation of a function using GPU - based calculations applied to image segmentation problems was substantiated in [11]. In this work, error estimates when approximating a curve $y=f(x)$ by interpolation and approximation algorithms are proposed, the question of the optimal curve partitioning for a given number of nodes is considered.

A numerical method to analyze and model planar shapes via polygonal curve evolutions is studied in [12, 13]. Consider a smooth curve each point of which moves in the normal direction with speed equal to a function of the curvature and curvature derivatives at the point. Chosen the speed function properly, the evolving curve converges to a desired shape.

Some theoretical results concerning estimate of the Hausdorff distance between the curve and the polyline based on the Sobolev space were considered in [14].

Algorithms for adaptive polyline interpolation of an ordered discrete set of points, allow to dilute the original set and obtain a polyline with fewer nodes. An overview of these methods is given in [15].

General algorithms for asymptotic optimal interpolation and approximation of curves by technological lines (including polylines) were considered in [1]. The characteristic of this approach is that it gives a polyline with the least number of nodes. Analyzing these studies, it is possible to identify unresolved issues, namely: substantiation of the number of points of preliminary sampling curve, choice of numerical integration method when calculating values of nodes regulator function, methods of its interpolation, etc.

\section{MATERIALS AND METHODS}

The approach to obtaining the nodes of the asymptotically optimal partition of the curve is to interpolate the values of the integral distribution function. The following algorithm can be proposed for this purpose.

Let's define a step of a uniform sampling $h=\frac{T}{N}$ and then receive a set of curve points

$$
\mathrm{P}_{i}=\mathbf{p}\left(\frac{i}{N}\right),(i=0,1, \ldots, N),
$$

corresponding to a discrete sequence of curve parameter values $\Delta_{N}^{t}\left\{t_{i}=0, \frac{1}{N}, \frac{2}{N}, \ldots, T\right\}$.

To obtain the values of the nodes sequence $\Delta_{m}^{t}=\left\{t_{j, m}^{*}\right\}(j=0,1, \ldots, m)$ for the asymptotically optimal partition of the curve by one of the known numerical integration methods we obtain a sequence of values of $s_{i}=$ $\Psi\left(t_{i}\right), t_{i} \in \Delta_{N}^{t},(i=0,1, \ldots, N)$ function (6) at the nodes of the initial uniform grid $\Delta_{N}^{t}$. And, further, interpolate these values between the nodes, we find the value of the inverse function $t_{j}=\Psi_{-1}\left(s_{j}\right)$ with a uniform already, according to the right part (5), the distribution of $s_{j}$ values from 0 to $s_{N}=\Psi\left(t_{N}\right)$.

The number of polyline segments, according to (3), will take the form

$$
m=\left[\frac{s_{N}}{\sqrt{8 \varepsilon}}\right]+1
$$

The $s$-values for uniform grid spacing $\Delta_{m}^{s}\left\{s_{j}, j=0,1, \ldots, m\right\}$ is calculated by the expression

$$
s_{j}=\frac{j s_{N}}{m} .
$$

Let define the values of the curve parameter $t_{j}^{*}$, which form the asymptotically - optimal sequence of polyline nodes. The simplest approach is to construct a linear interpolation of the function $s=\Psi(t)$ by the initial uniform grid values of $t-\Delta_{N}^{t}$. Finding the intersection of the grid lines $s=s_{j}$ and the graphics of $\Psi(t)$ constructed on the grid $\Delta_{N}^{t}$, we obtain the corresponding values of the sequence from the following expression of the inverse dependence.

$$
t_{j}^{*}=t_{i}+\frac{T\left(s_{j}-s_{i}\right)}{N\left(s_{i+1}-s_{i}\right)} .\left(s_{i} \leq s_{j} \leq s_{i+1}, t_{i} \in \Delta_{N}^{t}\right) .
$$


An alternative approach that can be proposed is interpolation of integral function $\Psi(t)$ by a linear rational Bspline. The principles of this approach were considered in $[16,17]$. This method provides $C^{l}$ continuity at the interpolation nodes. In the proposed method each interpolation interval $\left[t_{i}, t_{i+1}\right]$ corresponds to the LRBS curve with an open two-interval knot vector $-\left[t_{i}, t_{i}, t_{i+1 / 2}, t_{i+1}, t_{i+1}\right]$, where $t_{i+1 / 2}$ - some internal parameter value within the interval. The value $t_{i+1 / 2}$ can be determined by a coefficient $\lambda_{i, i+1}(0 \leq \lambda \leq 1)$, then we define

$$
t_{i+1 / 2}=\left(1-\lambda_{i, i+1}\right) t_{i}+\lambda_{i, i+1} t_{i+1}
$$

The monotonic increasing linear rational functions that interpolate the function between the values $s_{i}=\Psi\left(t_{i}\right)$ and $\mathrm{s}_{i+1}=\Psi\left(\mathrm{t}_{i+1}\right)$ at the ends of the interval will take the form:

$$
\begin{aligned}
& - \text { for } t_{i} \leq t<t_{i+1 / 2}: \\
& s_{i, i+1 / 2}=\frac{w_{i} s_{i}\left(t_{i+1 / 2}-t\right)+w_{i+1 / 2} s_{i+1 / 2}\left(t-t_{i}\right)}{w_{i}\left(t_{i+1 / 2}-t\right)+w_{i+1 / 2}\left(t-t_{i}\right)},
\end{aligned}
$$$$
- \text { for } t_{i+1 / 2} \leq t<t_{i+1}:
$$$$
s_{i+1 / 2, i+1}=\frac{w_{i+1 / 2} s_{i+1 / 2}\left(t_{i+1}-t\right)+w_{i+1} s_{i+1}\left(t-t_{i+1 / 2}\right)}{w_{i+1 / 2}\left(t_{i+1}-t\right)+w_{i+1}\left(t-t_{i+1 / 2}\right)} .
$$

Having the values of the interpolated function and its derivatives $\left(s_{i}^{\prime}, s_{i+1}^{\prime}\right)$ at the ends of the interval, the coefficients of the LRB - spline are defined according to the following steps:

- the value of one of the weights according to [16] can be taken arbitrarily - it will be a scale factor for other weights, we are free to choose any positive value for the first weight $w_{i}$; [16]:

- then the last weight is obtained from the expression

$$
w_{i+1}=\sqrt{\frac{s_{i}^{\prime}}{s_{i+1}^{\prime}}} w_{i}
$$

- the value of $\lambda_{i, i+1}$ can be obtained according to [17] as following:

$$
\lambda_{i, i+1}=\left\{\begin{array}{c}
\frac{s_{i}^{\prime}-\left(s_{i}^{\prime} s_{i+1}^{\prime}\right)^{1 / 2}}{s_{i}^{\prime}-s_{i+1}^{\prime}}, \text { при } s_{i}^{\prime} \neq s_{i+1}^{\prime} ; \\
\frac{1}{2}, \text { при } s_{i}^{\prime}=s_{i+1}^{\prime} ;
\end{array}\right.
$$

- the value of the $s_{i+1 / 2}$ at the internal point, will have meet the conditions of smoothness [16]:

$$
s_{i+1 / 2}=\frac{\left(1-\lambda_{i, i+1}\right) w_{i} s_{i}+\lambda_{i, i+1} w_{i+1} s_{i+1}}{\left(1-\lambda_{i, i+1}\right) w_{i}+\lambda_{i, i+1} w_{i+1}}
$$

- the expression for the internal weight has the form:

$$
w_{i+1 / 2}=\frac{t_{i+1}-t_{i}}{s_{i+1}-s_{i}}\left[\left(1-\lambda_{i, i+1}\right) w_{i+1} s_{i+1}^{\prime}+\lambda_{i, i+1} w_{i} s_{i}^{\prime}\right] .
$$

Solving the equations (12) with respect to $t$, we obtain:

$$
\begin{aligned}
& - \text { for } s_{i} \leq s_{j} \leq s_{i+1 / 2}: \\
& t_{j}^{*}=\frac{w_{i} t_{i+1 / 2}\left(s_{j}-s_{i}\right)+w_{i+1 / 2} t_{i}\left(s_{i+1 / 2}-s_{j}\right)}{w_{i}\left(s_{j}-s_{i}\right)+w_{i+1 / 2}\left(s_{i+1 / 2}-s_{j}\right)} ; \\
& - \text { for } s_{i+1 / 2} \leq s_{j} \leq s_{i+1}: \\
& t_{j}^{*}=\frac{w_{i+1 / 2} t_{i+1}\left(s_{j}-s_{i+1 / 2}\right)+w_{i+1} t_{i+1 / 2}\left(s_{i+1}-s_{j}\right)}{w_{i+1 / 2}\left(s_{j}-s_{i+1 / 2}\right)+w_{i+1}\left(s_{i+1}-s_{j}\right)} .
\end{aligned}
$$

To estimate the modelling results and compare with the maximum approximation error bound, the equidistant method to the curve [1] can be used. The essence of this method is to construct internal and external equidistant to the reproducible curve. The method is to show constructed polyline together with the inner and outer equidistant to the curve.

The equidistant method provides the possibility of visual control over the behavior of the polyline relative to the limits of $\varepsilon$ - permissible "tube" for the original curve. However, the significant disadvantages of this approach are the impossibility of quantitative estimation of the approximation error bounds, the difficulty of visual control for small errors and for a large number of polyline segments.

To eliminate the disadvantages of the equidistant method, we consider the possibility of evaluation based on quantitative characteristics of the quality of curve reconstruction. It is natural to choose as such a characteristic the maximum distance $d_{j}^{\max }$ between the polyline segment $l_{j}$ and the corresponding curve $\operatorname{arc} \Gamma_{t_{j-1}^{*}}^{t_{j}^{*}}$ and to compare it with the given approximation error bound. Having calculated these distances for the entire polyline, we obtained a sequence of error values $\left\{d_{j, m}^{\max }\right\},(j=1, \ldots, m)$ where $d_{j}^{\max }==\max \left\{d\left(\Gamma_{t_{j-1}^{*}}^{t_{j}^{*}}, l_{j}\right)\right\}$. This sequence can be represented graphically as a bar chart, where the horizontal axis represents the number of polyline segment, 
and the vertical axis - the corresponding distance $d_{j}^{\max }$ from the curve to the polyline. To simplify the comparison with the error limit and to be able to analyze the results obtained at different values of accuracy, we introduce the concept of relative error of the segment $-\gamma_{j}$, for which we take the ratio of the maximum distance of the polyline segment to the approximation error bound $\gamma_{j}=d_{j}^{\max } / \varepsilon$. This means that the values of the relative error in the range from 0 to 1 satisfy the specified accuracy of the approximation, and values greater than one are beyond the error bound.

In the case of an interpolation polyline, the start and end points of its arbitrary segment lie on the curve and are defined by the values of the curve parameter $t_{j-1}^{*}$ and $t_{j}^{*}$. Thus, the arc of the curve interpolated by the current segment is determined by the interval of the curve parameter $-\left(t_{j-1}^{*}, t_{j}^{*}\right)$.

Therefore, the distance between the $j$-th segment of the interpolation polyline and the point $\mathrm{M}\left(x_{\mathrm{M}}(t), y_{\mathrm{M}}(t)\right)$ on the curve, is determined by the equation

$$
d_{j}(t)=\left|\frac{A_{j} x_{M}+B_{j} y_{M}+C_{j}}{\sqrt{A_{j}^{2}+B_{j}^{2}}}\right|,
$$

where $A_{j}=y_{j-1}-y_{j}, B_{j}=x_{j}-x_{j-1}, C_{j}=y_{j} x_{j-1}-x_{j} y_{j-1}$.

To obtain the local extrema of function (18), we differentiate its right-hand side by $t$ and, equaling it to zero, we have

$$
A_{j} x^{\prime}(t)+B_{j} y^{\prime}(t)=0 .
$$

Having obtained the roots of this equation, which is within the arc range of values, we choose the maximum from them $-d_{j}^{\max }$.

If the curve is composed of several elementary curve arcs, the nodal points of the interpolation polyline may belong to different components of the curves. This means that the distance between the curve and the polyline must be obtained among all the arcs of the curve that are within the interpolation interval of a segment. For example, in the case of $\mathrm{B}-$ spline based on an open knot vector $\mathrm{T}\left(t_{i} \in[0, \mathrm{~T}]\right)$ we find the following values of the knot vector $t_{i} \geq t_{j}$ (for $t_{i-1}<t_{j}$ ) and $t_{i-k} \geq t_{j-1}$ (for $t_{i-k-1}<t_{j-1}$ ), which correspond to the $j$-th segment of the polyline. For each spline arc within the interval $\left(t_{i}, t_{i-k-1}\right)$ we find the distances according to the above algorithm $-\left\{d_{k}^{\max }\right\}$. And, then choose the maximum of them $d_{j}^{\max }=\max \left\{d_{k}^{\max }\right\}$.

\section{EXPERIMENTS}

Experiments for reconstruction of curves by an asymptotically optimal interpolation algorithm aimed to investigate the influence of algorithm parameters and methods on the quality of reconstruction results. Such influencing factors include: the number of the initial uniform sampling nodes for the integral function $-N$, the error in calculating the values of the function $\Psi-\delta^{\Psi}$, the interpolation method of this function.

Two plane convex curve (closed and open) were chosen to the reproduction modelling. The first (Fig. 1) is a Bezier curve of the sixth order with the coordinates of the control polygon $(0.0 ; 0.0),(0.55 ; 6.9),(11.8 ; 9.2),(16.5$; $6.25),(22.0 ; 3.2), 24.5 ; 0.0),(18.0 ;-1.0)$. The second (Fig. 2) is called the Pascal snail and has the following parameters: radius of the base circle -2.5 , offset -14 . Both curves do not contain inflection points.

In this work, we will focus on the study of the influence on the results of recconstruction the initial sampling of the function (6) $-N$ at a constant integration error $\delta^{\Psi}$. The interpolation of the obtained values will be implemented according to the linear algorithm - formula (11) and using LRB-spline - formula (17). This will allow to compare the results of the approximation and define the sufficient value of the parameter $N$.

In [1], the following simple dependence was used to define the value of $N$

$$
N=\left[\frac{1}{\varepsilon}\right]+1,
$$

which considers only the recconstruction error bound and does not depend on the properties of the curve itself. In addition, this expression does not take in account how the values of the integral function are interpolated at the intervals between the sampling nodes. For the further comparison, we give a set of approximation error bounds and the corresponding the number of sampling nodes, which are calculated by (20) and summarized in Table 1 .

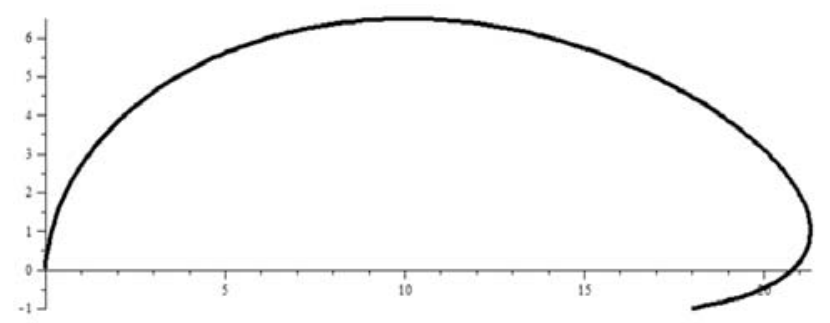

Figure 1 - Bezier curve reconstructed by polylines

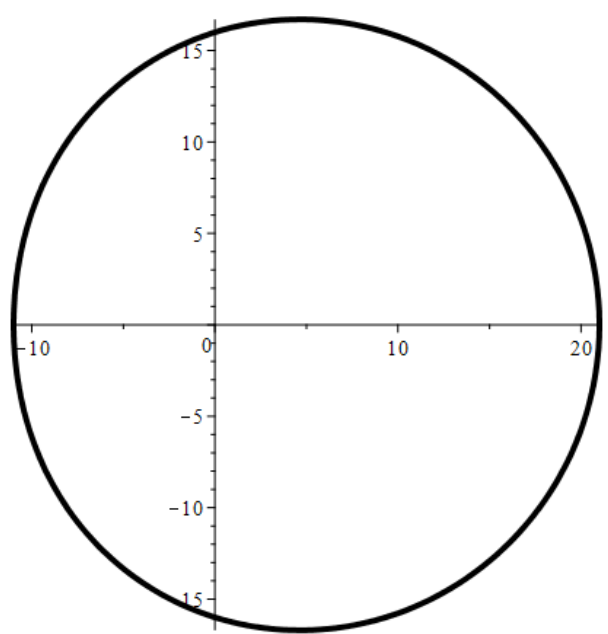

Figure 2 - Pascal's snail reconstructed by polylines 
Table 1 - The value of the number of sampling nodes obtained by the expression (23)

\begin{tabular}{|c|c|c|c|c|c|c|c|}
\hline Error bound $-\varepsilon$ & 0.0001 & 0.001 & 0.005 & 0.0075 & 0.01 & 0.025 & 0.05 \\
\hline $\begin{array}{c}\text { Number of nodes } \\
\text { for the initial sam- } \\
\text { pling }-N\end{array}$ & 10001 & 1001 & 201 & 134 & 101 & 0.1 & 41 \\
\hline
\end{tabular}

For the linear method of interpolation, we take as a basis the estimate of the error and starting from it we will define the number of sampling points and fixe it impact on the distribution of reconstruction errors. According to [17], the estimate of the maximum error of linear interpolation on a segment $\left[t_{i-1}, t_{i}\right]$ has the form

$$
\delta_{i}=\max _{\left[t_{i-1}, t_{i}\right]}\left|f(t)-L_{1}(t)\right| \leq h^{2} \frac{M_{2, i}}{8},
$$

where $M_{2, i}=\max _{\left[t_{i-1}, t_{i}\right]}\left|f^{\prime \prime}(t)\right|$.

Given that we have a constant sampling step $h=\frac{T}{N}$ and extending the estimate to all intervals $M_{2}=\max _{T}\left|f^{\prime \prime}(t)\right|$ we find

$$
N \geq T \sqrt{\frac{M_{2}}{8 \delta}} .
$$

For certainty, we define

$$
N=\left\lceil T \sqrt{\frac{M_{2}}{8 \delta}}\right\rceil+1
$$

As follows from (23), linear interpolation has the convergence order $O\left(h^{2}\right)$, and the error bound of linear rational interpolation was estimated in [18] as $O\left(h^{3}\right)$, i.e., as a case of quadratic interpolation. The estimate of quadratic interpolation has the form

$$
\delta_{i}=\max _{\left[t_{i-1}, t_{i}\right]}\left|f(t)-L_{2}(t)\right| \leq \frac{\sqrt{3} h^{3}}{27} M_{3, i},
$$

where $M_{3, i}=\max _{\left[t_{i-1}, t_{i}\right]}\left|f^{\prime \prime \prime}(t)\right|$.

Based on this estimate, by analogy with linear interpolation, we will have

$$
N=\left\lceil\frac{T \sqrt[6]{3}}{3} \sqrt[3]{\frac{M_{3}}{\delta}}\right\rceil+1
$$

We begin the choosing of the $\delta$ value with the estimate $\delta=\varepsilon$, and further, we will reduce this value by division on $2^{k}$ (for linear interpolation case) and $3^{k}$ (for LRBS case). For calculating the values of the integral function $\Psi_{i}$, we use Clenshaw-Curtis quadrature with a constant value of the integration error $\delta^{\Psi}=0.510^{-10}$. To explain the reconstruction results, we will compare the bar charts of error distributions at different values of $\delta$, shown on the same scale factor - Fig. 3-6.

For the analysis of modeling data, it is more convenient to present results in the form of statistical characteristics of errors distributions obtained for sequences of polylines segments. These characteristics are:

maximum and minimum values of the errors sequence $\gamma_{\max }, \gamma_{\min }$, mean $-\bar{\theta}$, median, the range of errors for the sequence of segments $-\Delta$, standard deviation $-\sigma$. The characteristics are presented in tables that correspond to the approximations of the curve having a given error bound and the same number of polyline segments. The results are obtained for different number of the integral function sampling nodes.

\section{RESULTS}

Tables 2-5 show the values of the error distribution characteristics for the curves (Fig. 1, 2) using a linear interpolation of the integral function (6) by expressions (11). From the presented results it follows that at values $\delta$ $=\varepsilon / 64 \ldots \varepsilon / 256$ the segments errors are stabilized being within the range of admissible values close to its upper limit $-0.9 \ldots 0.98$. The comparison of the sample variances for the cases $\varepsilon / 128, \varepsilon / 256$ and $\varepsilon^{2}$ according to the Cochren test with a confidence level of 0.95 did not show statistical significance. Therefore, a further increasing the number of sampling nodes did not have a significant effect on the approximation results.

Further, we will consider the effect of the integral function interpolation by LRB-spline and compare them with the results already obtained by linear interpolation.

In LRBS case, we will start to change the $\delta$-value in (25) from the estimate $\delta=3 \varepsilon$. Tables $6-9$ show the results for the interpolation of the integral function by a linear rational B-spline under similar conditions to the linear method. The relative approximation error according to these tables was stabilized at values of $\delta=\varepsilon / 81 \ldots \varepsilon / 243$ at values close to those observed with the linear method. Comparison of sample variances by the Cochren's test starting from $\delta=\varepsilon / 9 \ldots \varepsilon / 27$ did not show statistical significance. If we also compare the results of the corresponding tables for the linear and LRBS interpolation of the integral function, it becomes clear that to achieve the same results of approximation by the spline method required 5-6 times fewer sampling nodes than by the linear method. 
e-ISSN 1607-3274 Радіоелектроніка, інформатика, управління. 2021. № 3 p-ISSN 2313-688X Radio Electronics, Computer Science, Control. 2021. № 3

Table 2 - The results of the reconstruction for the curve - Fig. 1 and $\varepsilon=0.001$ (number of polyline segments $m=122$ )

\begin{tabular}{|c|c|c|c|c|c|c|c|c|c|c|}
\hline \multirow{2}{*}{$\begin{array}{l}\text { Statistical char- } \\
\text { acteristic }\end{array}$} & \multicolumn{10}{|c|}{ The interpolation error of the integral function, $\delta$} \\
\hline & $\varepsilon$ & $\varepsilon / 2$ & $\varepsilon / 4$ & $\mathbf{\varepsilon} / \mathbf{8}$ & $\varepsilon / 16$ & $\varepsilon / 32$ & $\varepsilon / 64$ & $\varepsilon / 128$ & $\varepsilon / 256$ & $\varepsilon^{2}$ \\
\hline$\gamma_{\max }$ & 0.989389 & 0.98049 & 0.974665 & 0.972353 & 0.972083 & 0.971481 & 0.971236 & 0.971281 & 0.97122 & 0.9712 \\
\hline$\gamma_{\min }$ & 0.953614 & 0.961996 & 0.967626 & 0.969393 & 0.969849 & 0.970404 & 0.970604 & 0.97069 & 0.970703 & 0.970723 \\
\hline$\Delta$ & 0.035775 & 0.018494 & 0.007039 & 0.002959 & 0,002234 & 0.001077 & 0.000632 & 0.000591 & 0,000516 & 0.00047 \\
\hline \multirow[t]{2}{*}{$\bar{\theta}$} & 0.970928 & 0.970915 & 0.970912 & 0.970915 & 0,970911 & 0.970911 & 0.970911 & 0.970909 & 0.970912 & 0.97091 \\
\hline & 0.970446 & 0.970743 & 0.97083 & 0.970909 & 0.970871 & 0.970897 & 0.9709 & 0.970899 & 0.970911 & 0.97091 \\
\hline$\sigma$ & 0.007305 & 0.00322 & 0.001057 & 0.000627 & 0.000401 & 0.000196 & 0.000141 & 0.000108 & 0.000101 & $9.7210^{-5}$ \\
\hline$N$ & 73 & 102 & 144 & 203 & 287 & 405 & 572 & 808 & 1143 & 2257 \\
\hline
\end{tabular}

$\gamma$

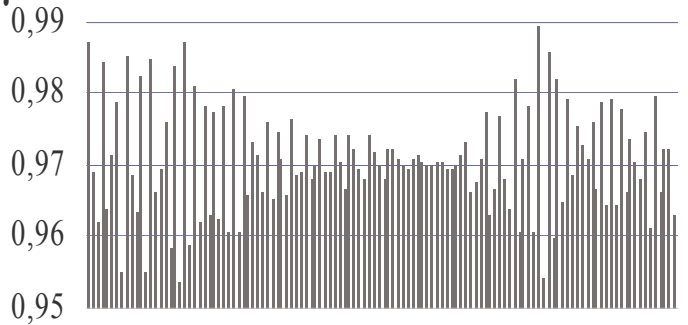

110192837465564738291100109118

Segment number

Figure 3 - Errors distributions for the reconstruction of the curve - Fig. 1 (given error bound $\varepsilon=0.001$ and $\delta=\varepsilon$ )

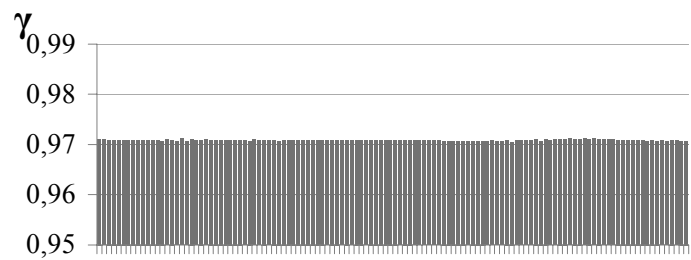

$\begin{array}{llllllllllll}1 & 10 & 19 & 28 & 37 & 46 & 55 & 64 & 73 & 82 & 91 & 100109118\end{array}$

Segment number

Figure 4 - Errors distributions for the reconstruction of the curve - Fig. 1 (given error bound $\varepsilon=0.001$ and $\delta=\varepsilon / 64$ )

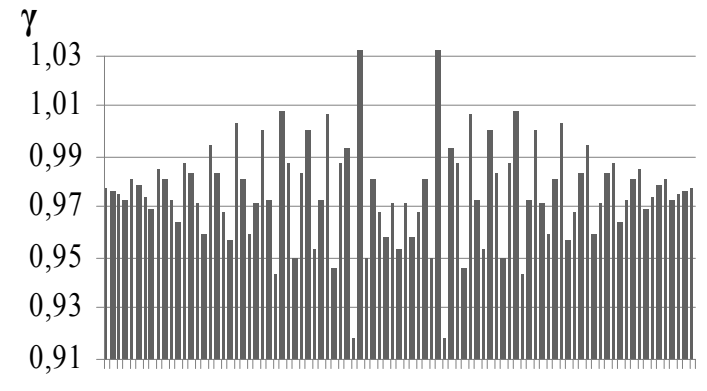

Segment number

Figure 5 - Errors distributions for the reconstruction of the curve - Fig. 2 (given error bound $\varepsilon=0.01$ and $\delta=\varepsilon$ )

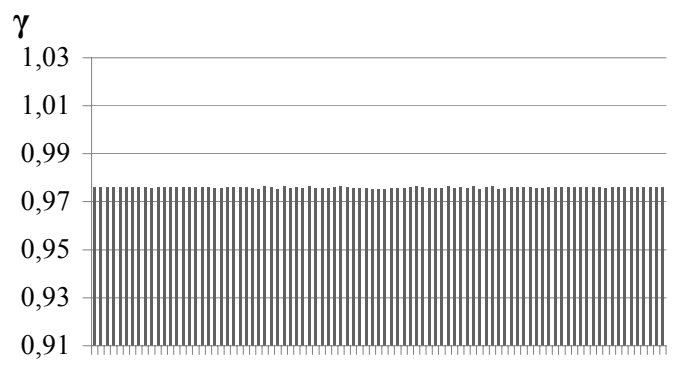

161116212631364146515661667176818691

Segment number

Figure 6 - Errors distributions for the reconstruction of the curve - Fig. 2 (given error bound $\varepsilon=0.01$ and $\delta=\varepsilon / 64$ )

Table 3 - The results of the reconstruction for the curve - Fig. 1 and $\varepsilon=0.01$ (number of polyline segments $m=40$ )

\begin{tabular}{|l|l|l|l|l|l|l|l|l|l|l|}
\hline \multirow{2}{*}{$\begin{array}{l}\text { Statistical charac- } \\
\text { teristic }\end{array}$} & \multicolumn{9}{|c|}{ The interpolation error of the integral function, $\delta$} \\
\cline { 2 - 10 } & $\boldsymbol{\varepsilon}$ & $\mathbf{\varepsilon} / \mathbf{2}$ & $\mathbf{\varepsilon} / \mathbf{4}$ & $\mathbf{\varepsilon} / \mathbf{8}$ & $\mathbf{\varepsilon} / \mathbf{1 6}$ & $\mathbf{\varepsilon} / \mathbf{3 2}$ & $\mathbf{\varepsilon} / \mathbf{6 4}$ & $\mathbf{\varepsilon} / \mathbf{1 2 8}$ & $\mathbf{\varepsilon} / \mathbf{2 5 6}$ & $\mathbf{\boldsymbol { \varepsilon } ^ { \mathbf { 2 } }}$ \\
\hline$\gamma_{\max }$ & 0.957806 & 0.934061 & 0.914664 & 0.908149 & 0.90704 & 0.905889 & 0.905787 & 0.905455 & 0.905296 & 0.905335 \\
\hline$\gamma_{\min }$ & 0.852996 & 0.876438 & 0.894885 & 0.897718 & 0.899909 & 0.901159 & 0.901194 & 0.901487 & 0.901521 & 0.901572 \\
\hline$\Delta$ & 0.10481 & 0.057623 & 0.019779 & 0.010431 & 0.00713 & 0.004729 & 0.004592 & 0.003968 & 0.003775 & 0.003763 \\
\hline $\bar{\theta}$ & 0.903137 & 0.903025 & 0.902994 & 0.902989 & 0.902987 & 0.902986 & 0.902987 & 0.902987 & 0.902986 & 0.902986 \\
\hline median & 0.900533 & 0.900686 & 0.901924 & 0.902694 & 0.902683 & 0.902828 & 0.902873 & 0.902906 & 0.902914 & 0.902931 \\
\hline$\sigma$ & 0.022944 & 0.011551 & 0.004583 & 0.002402 & 0.001687 & 0.00108 & 0.001008 & 0.000904 & 0.000875 & 0.000853 \\
\hline$N$ & 24 & 33 & 47 & 65 & 92 & 129 & 182 & 257 \\
\hline
\end{tabular}


e-ISSN 1607-3274 Радіоелектроніка, інформатика, управління. 2021. № 3 p-ISSN 2313-688X Radio Electronics, Computer Science, Control. 2021. № 3

Table 4 - The results of the reconstruction for the curve - Fig. 2 and $\varepsilon=0.001$ (number of polyline segments $m=286$ )

\begin{tabular}{|c|c|c|c|c|c|c|c|c|c|c|}
\hline \multirow{2}{*}{$\begin{array}{l}\text { Statistical } \\
\text { characteristic }\end{array}$} & \multicolumn{10}{|c|}{ The interpolation error of the integral function, $\delta$} \\
\hline & $\varepsilon$ & $\varepsilon / 2$ & $\varepsilon / 4$ & $\varepsilon / 8$ & $\varepsilon / 16$ & $\varepsilon / 32$ & $\varepsilon / 64$ & $\varepsilon / 128$ & $\varepsilon / 256$ & $\varepsilon^{2}$ \\
\hline$\gamma_{\max }$ & 1.00654 & 0.99826 & 0.99214 & 0.98935 & 0.98913 & 0.98854 & 0.98828 & 0.98822 & 0.98821 & 0.98821 \\
\hline$\gamma_{\min }$ & 0.9693 & 0.97773 & 0.98395 & 0.98678 & 0.98681 & 0.98743 & 0.98768 & 0.98769 & 0.98773 & 0.98774 \\
\hline$\Delta$ & 0.03724 & 0.02053 & 0.00819 & 0.00257 & 0,00232 & 0,00111 & 0.0006 & 0.00053 & 0.00048 & 0.00047 \\
\hline $\bar{\theta}$ & 0.98798 & 0.987977 & 0.98797 & 0.987955 & 0.98797 & 0.987969 & 0.987963 & 0.987971 & 0.987967 & 0.987966 \\
\hline median & 0.98799 & 0.98798 & 0.987935 & 0.98798 & 0.98798 & 0.98796 & 0.98796 & 0.98796 & 0.98797 & 0.98797 \\
\hline$\sigma$ & 0.006474 & 0.003764 & 0.001683 & 0.00052 & 0.00035 & 0.000216 & 0.000121 & $8.5610^{-5}$ & $7.4710^{-5}$ & $6.9610^{-5}$ \\
\hline$N$ & 87 & 122 & 172 & 243 & 343 & 484 & 684 & 966 & 1366 & 7627 \\
\hline
\end{tabular}

Table 5 - The results of the reconstruction for the curve - Fig. 2 and $\varepsilon=0.01$ (number of polyline segments $m=91$ )

\begin{tabular}{|c|c|c|c|c|c|c|c|c|c|c|}
\hline \multirow{2}{*}{$\begin{array}{l}\text { Найменування } \\
\text { показника }\end{array}$} & \multicolumn{10}{|c|}{ The interpolation error of the integral function, $\delta$} \\
\hline & $\varepsilon$ & $\varepsilon / 2$ & $\varepsilon / 4$ & $\varepsilon / 8$ & $\varepsilon / 16$ & $\varepsilon / 32$ & $\varepsilon / 64$ & $\varepsilon / 128$ & $\varepsilon / 256$ & $\varepsilon^{2}$ \\
\hline$\gamma_{\max }$ & 1.031872 & 0.999084 & 0.988514 & 0.979086 & 0.978574 & 0.977092 & 0.976432 & 0.976231 & 0.975974 & 0.975947 \\
\hline$\gamma_{\min }$ & 0.918589 & 0.953424 & 0.964541 & 0.971311 & 0,972784 & 0,974536 & 0.975064 & 0.975238 & 0.975292 & 0.975361 \\
\hline$\Delta$ & 0.113283 & 0.04566 & 0.023973 & 0.007775 & 0.00579 & 0.002556 & 0.001368 & 0.000993 & 0.000682 & 0.000586 \\
\hline $\bar{\theta}$ & 0.975881 & 0.975812 & 0.975791 & 0.975784 & 0.975784 & 0.975783 & 0.975783 & 0.975783 & 0.975783 & 0.975783 \\
\hline median & 0.975494 & 0.975934 & 0.975165 & 0.976036 & 0.975893 & 0.97578 & 0.975793 & 0.975794 & 0.975787 & 0.975783 \\
\hline$\sigma$ & 0.019654 & 0.010643 & 0.005374 & 0.001766 & 0.001046 & 0.00058 & 0.000264 & 0.000185 & 0.000101 & $910^{-5}$ \\
\hline$N$ & 28 & 40 & 55 & 78 & 109 & 154 & 217 & 307 & 433 & 764 \\
\hline
\end{tabular}

Table 6 - The results of the reconstruction for the curve - Fig. 1 and $\varepsilon=0.001$ (number of polyline segments $m=122$ )

\begin{tabular}{|l|l|l|l|l|l|l|l|l|}
\hline \multirow{2}{*}{$\begin{array}{l}\text { Statistical } \\
\text { characteristic }\end{array}$} & \multicolumn{1}{|c|}{ The interpolation error of the integral function, $\delta$} & \multicolumn{1}{|c|}{$\boldsymbol{\varepsilon} / \mathbf{9}$} & $\boldsymbol{\varepsilon} / \mathbf{2 7}$ & $\boldsymbol{\varepsilon} / \mathbf{8 1}$ & $\boldsymbol{\varepsilon} / \mathbf{2 4 3}$ & $\boldsymbol{\varepsilon}^{\mathbf{3}}$ \\
\cline { 2 - 10 } & $\mathbf{3 \varepsilon}$ & $\boldsymbol{\varepsilon}$ & $\boldsymbol{\varepsilon} / \mathbf{3}$ & 0.971373 & 0.9713 & 0.971228 & 0.971232 & 0.971195 \\
\hline$\gamma_{\max }$ & 0.973099 & 0.972094 & 0.971562 & 0.9713 & 0.970705 & 0.970729 \\
\hline$\gamma_{\min }$ & 0.967027 & 0.969814 & 0.97064 & 0.970705 & 0.970726 & 0.970728 & 0.970705 \\
\hline $\bar{\theta}$ & 0.006072 & 0.00228 & 0.000922 & 0.000667 & 0.000574 & 0.000501 & 0.000527 & 0.000466 \\
\hline median & 0.97091 & 0.970914 & 0.970913 & 0.970914 & 0.970912 & 0.970914 & 0.970914 & 0,970911 \\
\hline$\sigma$ & 0.970872 & 0.970909 & 0.970898 & 0.970908 & 0.97091 & 0.970909 & 0.970909 & 0.970908 \\
\hline$N$ & 0.000701 & 0.000306 & 0.000148 & 0.000109 & 0.000102 & 0.0001 & $9.83 \mathrm{E}-05$ & $9.5210^{-5}$ \\
\hline
\end{tabular}

Table 7 - The results of the reconstruction for the curve - Fig. 1 and $\varepsilon=0.01$ (number of polyline segments $m=40$ )

\begin{tabular}{|l|l|l|l|l|l|l|l|l|}
\hline \multirow{2}{*}{$\begin{array}{l}\text { Statistical } \\
\text { characteristic }\end{array}$} & \multicolumn{8}{|c|}{ The interpolation error of the integral function, $\delta$} \\
\cline { 2 - 9 } & $\mathbf{3 \varepsilon}$ & $\boldsymbol{\varepsilon}$ & $\boldsymbol{\varepsilon} / \mathbf{3}$ & $\mathbf{\varepsilon} / \mathbf{9}$ & $\mathbf{\varepsilon} / \mathbf{2 7}$ & $\mathbf{\varepsilon} / \mathbf{8 1}$ & $\mathbf{\varepsilon} / \mathbf{2 4 3}$ \\
\hline$\gamma_{\max }$ & 0.911873 & 0.908855 & 0.906987 & 0.90518 & 0.905401052 & 0.905290953 & 0.905338795 & 0.905324594 \\
\hline$\gamma_{\min }$ & 0.898304 & 0.900459 & 0.901631 & 0.901539 & 0.901569423 & 0.901586084 & 0.901585175 & 0.901584787 \\
\hline $\bar{\theta}$ & 0.013569 & 0.008397 & 0.005356 & 0.003642 & 0.003831629 & 0.003704868 & 0.003753621 & 0.003739807 \\
\hline median & 0.902988 & 0.902987 & 0.902986 & 0.902986 & 0.902986498 & 0.902986386 & 0.902986403 & 0.902986184 \\
\hline$\sigma$ & 0.902984 & 0.902739 & 0.902931 & 0.90293 & 0.902928449 & 0.902927493 & 0.902928085 & 0.90292768 \\
\hline$N$ & 0.002580 & 0.00162 & 0.001009 & 0.000847 & 0.00084955 & 0.000845842 & 0.000845356 & 0.000845317 \\
\hline
\end{tabular}

Table 8 - The results of the reconstruction for the curve - Fig. 2 and $\varepsilon=0.001$ (number of polyline segments $m=286$ )

\begin{tabular}{|c|c|c|c|c|c|c|c|c|}
\hline \multirow{2}{*}{$\begin{array}{l}\text { Statistical } \\
\text { characteristic }\end{array}$} & \multicolumn{8}{|c|}{ The interpolation error of the integral function, $\delta$} \\
\hline & $3 \varepsilon$ & $\varepsilon$ & $\varepsilon / 3$ & $\varepsilon / 9$ & $\varepsilon / 27$ & $\varepsilon / 81$ & $\varepsilon / 243$ & $\varepsilon^{3}$ \\
\hline$\gamma_{\max }$ & 0.9911 & 0.98927 & 0.98829 & 0.98823 & 0.98822 & 0.98823 & 0.98823 & 0.98823 \\
\hline$\gamma_{\min }$ & 0.98623 & 0.98716 & 0.9876 & 0.98773 & 0.98772 & 0.98772 & 0.98772 & 0.98772 \\
\hline$\Delta$ & 0.00487 & 0.00211 & 0.00069 & 0.0005 & 0.0005 & 0.00051 & 0.00051 & 0.00051 \\
\hline $\bar{\theta}$ & 0.98797011 & 0.987963007 & 0.98797035 & 0.98796374 & 0.987962657 & 0.98796965 & 0.987970105 & 0.987969231 \\
\hline median & 0.988075 & 0.98801 & 0.98799 & 0.98797 & 0.98797 & 0.98797 & 0.98797 & 0.98797 \\
\hline$\sigma$ & 0.000535 & 0.000254 & 0.000113 & $8.027810^{-5}$ & $7.8686210^{-5}$ & $7.7413610^{-5}$ & $7.2142610^{-5}$ & $6.9267610^{-5}$ \\
\hline$N$ & 28 & 40 & 57 & 82 & 118 & 169 & 243 & 3872 \\
\hline
\end{tabular}


Table 9 - The results of the reconstruction for the curve - Fig. 2 and $\varepsilon=0.01$ (number of polyline segments $m=91$ )

\begin{tabular}{|c|c|c|c|c|c|c|c|c|}
\hline \multirow{2}{*}{$\begin{array}{l}\text { Statistical } \\
\text { characteristic }\end{array}$} & \multicolumn{8}{|c|}{ The interpolation error of the integral function, $\delta$} \\
\hline & $3 \varepsilon$ & $\varepsilon$ & $\varepsilon / 3$ & $\varepsilon / 9$ & $\varepsilon / 27$ & $\varepsilon / 81$ & $\varepsilon / 243$ & $\varepsilon^{3}$ \\
\hline$\gamma_{\max }$ & 0.984439 & 0.980645 & 0.977005 & 0.976055 & 0.975935 & 0.975909 & 0.975911 & 0.975908 \\
\hline$\gamma_{\min }$ & 0.968286 & 0.972696 & 0.973873 & 0.975333 & 0.975368 & 0.975312 & 0.975367 & 0.975367 \\
\hline$\Delta$ & 0.016153 & 0.007949 & 0.003132 & 0.000722 & 0.000567 & 0.000597 & 0.000544 & 0.000541 \\
\hline $\bar{\theta}$ & 0,975784121 & 0.975783604 & 0.975782813 & 0.975783154 & 0.975783374 & 0.975782956 & 0.975783121 & 0.975782791 \\
\hline median & 0.976166 & 0.976035 & 0,975893 & 0.97582 & 0.975794 & 0.975785 & 0.975783 & 0.975781 \\
\hline$\sigma$ & 0.002169927 & 0.001081117 & 0.00042438 & 0.000149687 & $9.1779410^{-5}$ & $8.6152410^{-5}$ & $8.5202910^{-5}$ & $8.5057810^{-5}$ \\
\hline$N$ & 14 & 19 & 27 & 39 & 55 & 79 & 114 & 389 \\
\hline
\end{tabular}

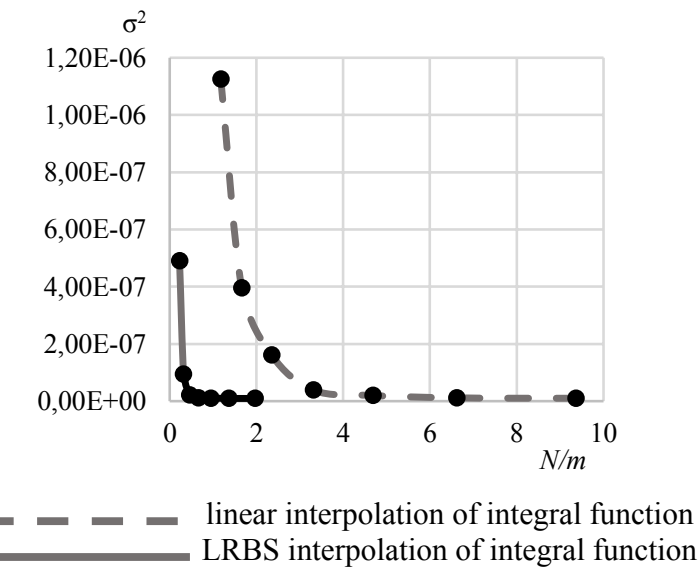

Figure 7 - Dependencies of sample variance on the ratio of the number of function sampling nodes $N$ to the number of approximation polyline segments $m$ for reconstructing the curve Fig. 1 with tolerance $\varepsilon=0.001$

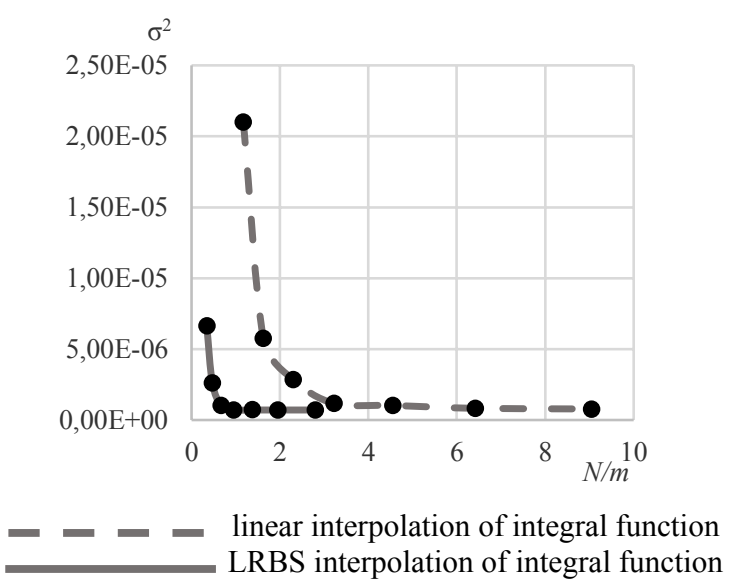

Figure 8 - Dependencies of sample variance on the ratio of the number of function sampling nodes $N$ to the number of approximation polyline segments $m$ for reconstructing the curve Fig. 1with tolerance $\varepsilon=0.01$

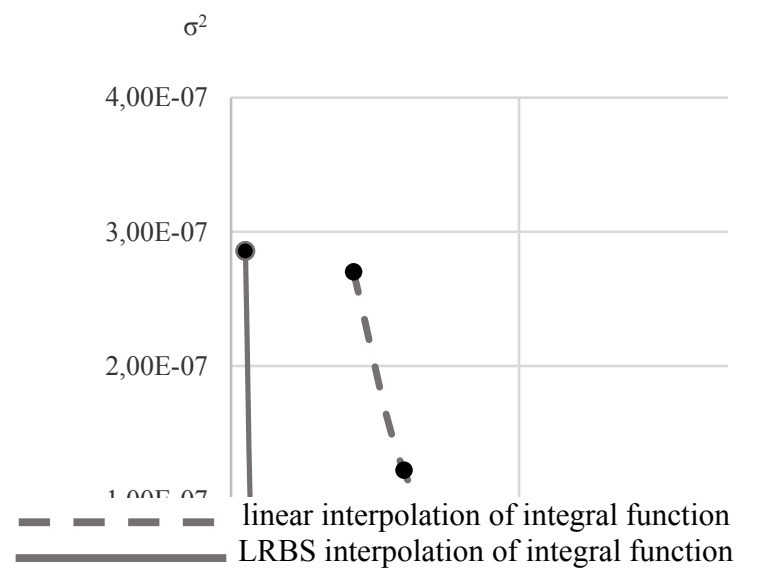

Figure 9 - Dependencies of sample variance on the ratio of the number of function sampling nodes $N$ to the number of approximation polyline segments $m$ for reconstructing the curve -

Fig. 2 with tolerance $\varepsilon=0.001$

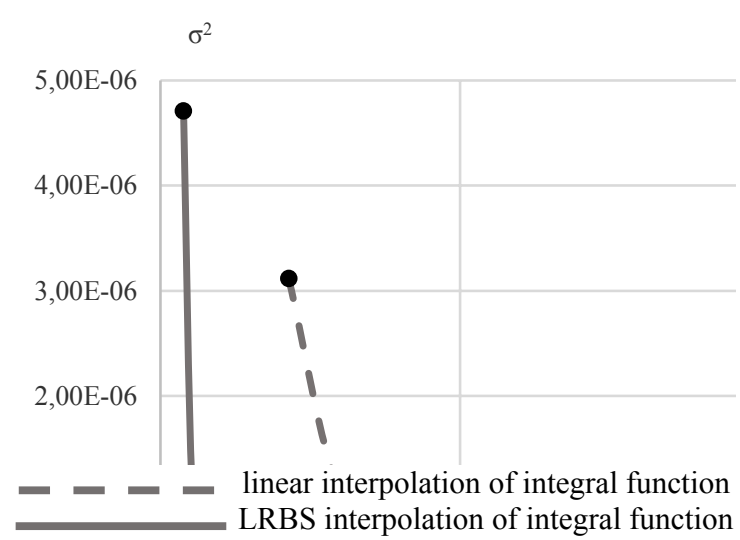

Figure 10 - Dependencies of sample variance on the ratio of the number of function sampling nodes $N$ to the number of approximation polyline segments $m$ for reconstructing the curve - Fig. 2 with tolerance $\varepsilon=0.01$

\section{DISCUSSION}

In more detail to see the difference between the two interpolation methods of the integral function (linear and LRBS), we compare the dependence of $\sigma^{2}$ on a number of sampling nodes. To reduce the effect of a given approximation error $\varepsilon$, we will determine the dependence on the 
ratio of the number $N$ of sampling points to the number of approximation segments $m$. On Fig. 7-10 we present these dependencies. It follows from these graphics that the rate of variance decreases when the nodes number ratio increasing was different for linear and for LRBS interpolations. This is confirmed by the fact that the approximation errors for LRBS interpolation were stabilized at the ratio up to $1 \div 2 \mathrm{~N} / \mathrm{m}$ (for the linear method at the ratio $5 \div 7 \mathrm{~N} / \mathrm{m}$ ).

Comparison of sampling node numbers for expressions (20) and (24), (25) shows that formula (20) can give both increased and decreased number of sampling points relative to the stabilization values (see Tables 2-9).

The experiments also showed the suitability of the models for the reconstruction of real parametric curves. The approximation error of polyline was stabilized at the level 90-98 percent of the error bound. This indicates that the asymptotically optimal algorithm pro-vides an error close to the upper limit of the error bound and the smallest number of the polyline segments.

\section{CONCLUSIONS}

The simulation of the reconstruction of convex plane parametric curves by an asymptotically optimal linear interpolation algorithm showed quite acceptable results without exceeding the approximation error bound in cases of a sufficient number of integral function sampling nodes.

The scientific novelty of obtained results is to identify the influence of increasing the number of the initial sampling of the integral function - the regulator on the quality of curves reconstruction. The effect is to improve the characteristics of approximation error distribution for the polyline segments sequence, namely, to reduce the variation of the error series, which corresponds to the stabilization of the error values around the mean value. Experimentally, it was confirmed that the increase in the number of integral function sampling nodes is bounded by the values of stabilization, after which the differences between the variances are not statistically significant. For the first time in the asymptotically optimal algorithm, LRBS interpolation of the integral function was used, which allows to significantly reduce (by $5 \div 6$ times) the number of sampling nodes and related calculations.

The practical significance of the work is to clarify and refine the parameters of the asymptotically optimal interpolation algorithm, which affects the results of curve reconstruction.

\section{ACKNOWLEDGEMENTS}

The work is supported by the state budget scientific research project of Simon Kuznets Kharkiv National University of Economic. The title of the project is "Modern methods and tools of analysis and development of information systems" (state registration number 0118U007183).

\section{REFERENCES}

1. Ligun A. A., Shumeiko A. A., Radzevitch S. P., Goodman E. D. Asymptotically optimal disposition of tangent points for approximation of smooth convex surfaces by polygonal functions, Computer Aided Geometric Design, 1997, Vol. 14, pp. 533-546. DOI: 10.1016/S0167-8396(96)000441.

2. de Figueiredo L. H. Adaptive sampling of parametric curves, Graphics Gems V, 1995, pp. 173-178. DOI: 10.1016/B978-0-12-543457-7.50032-2.

3. Pagani L., Scott P. J. Curvature based sampling of curves and surfaces, Computer Aided Geometric Design, 2018, Vol. 59, pp. 32-48. DOI: 10.1016/j.cagd.2017.11.004.

4. Hernández-Mederos V., Estrada-Sarlabous J. Sampling points on regular parametric curves with control of their distribution, Computer Aided Geometric Design, 2003, Vol. 20, Issue 6, pp. 363-382. DOI: 10.1016/S0167-8396(03)000797.

5. Zhong W., Luo X., Chang W. et al. A real-time interpolator for parametric curves, International Journal of Machine Tools and Manufacture, 2018, Vol. 125, pp. 133-145, DOI: 10.1016/j.ijmachtools.2017.11.010.

6. Bo P., Bartoň M., Pottmann H. Automatic fitting of conical envelopes to free-form surfaces for flank $\mathrm{CNC}$ machining, Computer-Aided Design, 2017, Vol. 91, pp. 84-94. DOI: 10.1016/ j.cad.2017.06.006.

7. Song Y., Yang Zh., Liu Y., Deng J. Function representation based slicer for 3D printing, Computer Aided Geometric Design, 2018, Vol. 62, pp. 276-293. DOI: 10.1016/j.cagd.2018.03.012.

8. Ohrhallinger S., Wimmer M. StretchDenoise: parametric curve reconstruction with guarantees by separating connectivity from residual uncertainty of samples, Proceedings of the 26th Pacific Conference on Computer Graphics and Applications, 2018, pp. 1-4. DOI: 10.2312/pg.20181266.

9. Cleghorn C. W., Engelbrecht A. P. Piecewise linear approximation of $n$-dimensional parametric curves using particle swarms, Swarm Intelligence. ANTS 2012. Lecture Notes in Computer Science. Springer, Berlin, Heidelberg, 2012, Vol. 7461, pp. 292-299. DOI: 10.1007/978-3-642-326509_30.

10. Ugaz C., Han L., Lim A. Knot locating in piecewise linear approximation [Electronic resource], arXiv preprint, arXiv 1909.03112, 2019, 13 p. Access mode: https://arxiv.org/abs/1909.03112

11. Berjón D., Gallego G., Cuevas C. et al. Optimal piecewise linear function approximation for GPU-based applications, IEEE Transactions on Cybernetics, 2016, Vol. 46 (11), pp. 2584-2595. DOI: 10.1109/TCYB.2015.2482365.

12. Belyaev A. G., Anoshkina E. V., Yoshizawa S., Yano M. Polygonal curve evolutions for planar shape modeling and analysis, International Journal of Shape Modeling, 1999, Vol. 05, No. 02, pp. 195-217. DOI: $10.1142 / \mathrm{S} 0218654399000174$.

13. Langer T., Belyaev A. G., Seidel H.-P. Asymptotic analysis of discrete normals and curvatures of polylines, SCCG '05: Proceedings of the 21st Spring Conference on Computer Graphics, $2005 . \quad$ pp. 229-232. DOI: 10.1145/1090122.1090160.

14. Gournay F., Kahn J., Lebrat L. Approximation of curves with piecewise constant or piecewise linear functions [Electronic resource], HAL Id hal-02284549, 2019, 17 p. Access mode: https://arxiv.org/pdf/1909.04582.pdf

15. Han Y., Samet H. LiMITS: An effective approach for trajectory simplification [Electronic resource], arXiv pre-print, 
arXiv:2010.08622v1, 2020, 13 p. Access mode: https://arxiv.org/abs/2010.08622v1

16. Fuhr R. D., Kallay M. Monotone linear rational spline interpolation, Computer Aided Geometric Design. 1992, Vol. 9, Issue 4, pp. 313-319. DOI:10.1016/0167-8396(92)90038-Q.

17. Epperson J. F. An introduction to numerical methods and analysis. New Jersey, Wiley, 2013, 615 p.
18. Oja P. Low degree rational spline interpolation, BIT Numerical Mathematics, 1997, Vol. 37, Issue 4, pp. 901-909. DOI: $10.1007 / \mathrm{BF} 02510359$

Received 15.06.2021. Accepted 19.08.2021.

УДК 512.2:004.94

\section{МОДЕЛЮВАННЯ АСИМПТОТИЧНО-ОПТИМАЛЬНОЇ КУСКОВО-ЛІНИЙНОЇ ІНТЕРПОЛЯЦІЇ ПЛОСКИХ ПАРАМЕТРИЧНИХ КРИВИХ}

Фролов О. В. - канд. техн. наук, доцент, доцент кафедри інформаційних систем Харківського національного технічного університету ім. С. Кузнеця, Харків, Україна.

Лоссв М. Ю. - канд. техн. наук, доцент, доцент кафедри інформаційних систем Харківського національного економічного університету імені Семена Кузнеця, Харків, Україна.

\section{АНОТАЦЯ}

Актуальність. Апроксимація кривих ламаними привертає увагу з метою іiї застосування до відтворення об'єктів складної форми на комп’ютері, верстатах з ЧПК та 3D принтерах. При цьому бажано мати найменшу кількість ланок ламаної, що замінює криву, зі збереженням необхідної точності відтворення.

Мета. Вдосконалення методу асимптотично оптимальної кусково-лінійної інтерполяції плоских параметричних кривих на основі дослідження впливу його параметрів та алгоритмів на розподіли похибок апроксимації реальних кривих ліній.

Метод. В роботі розглядається асимпточно-оптимальна інтерполяція плоских кривих, які задовольняють умові мінімальності кількості ланок апроксимації. Було запропоновано алгоритми отримання значень послідовності вузлів апроксимації на основі чисельного інтегрування функції - регулятора 3 подальшою лінійною та сплайновою інтерполяцією ії значень. Обгрунтовано методику оцінки результатів моделювання апроксимації реальних кривих, що базується на статистичній обробці рядів відносних похибок ланок ламаної. Проведено моделювання апроксимації реальних кривих та досліджено вплив на показники розподілу похибок кількісної характеристики ступеню дискретизації інтегральної функції - регулятора вузлів в залежності від методу інтерполяції значень інтегральної функції.

Результати. Проведені дослідження дозволили виявити вплив первісної дискретизації інтегральної функції - регулятора вузлів на якість відтворення кривих ламаними за асимптотично оптимальним алгоритмом та можливості визначення раціонального ступеню дискретизації при практичних розрахунках для відтворення виробів складної форми. Встановлено, що при достатній кількості точок дискретизації дисперсія розподілу похибок апроксимації стабілізується і збільшення цієї кількості на порядок не значно підвищує точність відтворення кривої. При цьому сплайнова інтерполяція значень інтегральної функції давала значно більшу швидкість стабілізації значень параметрів розподілів, що дозволяє знизити кількість вузлів первісної дискретизації у 5-6 разів маючи аналогічні показники точності апроксимації.

Висновки. Відтворення реальних плоских параметричних кривих опуклої форми ламаними за асимптотичнооптимальним алгоритмом інтерполяції показало цілком прийнятні результати без перевищення допустимої похибки апроксимації у випадках достатнього ступеню дискретизації значень інтегральної функції. Напрямками подальших досліджень може бути дослідження можливості спрощення розрахунків при обчисленні значень інтегральної функції розподілу чисельними методами, а також можливості використання дискретних аналогів похідних у виразі цієї функції.

КЛЮЧОВІ СЛОВА: інтерполяція, ламана, еквідистанта, інтегрування, плоска параметрична крива, похибка.

УДК 512.2:004.94

\section{МОДЕЛИРОВАНИЕ АСИМПТОТИЧНО-ОПТИМАЛЬНОЙ КУСОЧНО-ЛИНЕЙНОЙ ИНТЕРПОЛЯЦИИ ПЛОСКИХ ПАРАМЕТРИЧЕСКИХ КРИВЫХ}

Фролов О. В. - канд. техн. наук, доцент, доцент кафедры Информационных систем Харьковского национального экономического университета им. С. Кузнеца, Харьков, Украина.

Лосев М. Ю. - канд. техн. наук, доцент, доцент кафедры информационных систем Харьковского национального экономического университета имени Семена Кузнеца, Харьков, Украина.

\section{АННОТАЦИЯ}

Актуальность.. Аппроксимация кривых ломаными привлекает внимание с целью ее применения к восстановлению объектов сложной формы на компьютере, станках с ЧПУ и 3D принтерах. При этом желательно иметь наименьшее количество звеньев ломаной, заменяющей кривую, с сохранением необходимой точности аппроксимации.

Цель. Совершенствование метода асимптотически оптимальной кусочно-линейной интерполяции плоских параметрических кривых на основе исследования влияния его параметров и алгоритмов на распределения погрешностей при аппроксимации реальных кривых линий.

Метод. В работе рассматривается асимпточно-оптимальная интерполяция плоских кривых, удовлетворяющих условию минимальности количества звеньев аппроксимации. Было предложены алгоритмы получения значений последовательности узлов аппроксимации на основе численного интегрирования функции - регулятора с последующей линейной и сплайновой интерполяции ее значений. Обоснована методика оценки результатов моделирования аппроксимации реальных кривых, основанный на статистической обработке последовательностей относительных погрешностей звеньев ломаной. Проведено 
моделирование аппроксимации реальных кривых и исследовано влияние на показатели распределения погрешностей количественной характеристики степени дискретизации интегральной функции - регулятора узлов в зависимости от метода интерполяции значений интегральной функции.

Результаты. Проведенные исследования позволили выявить влияние первоначальной дискретизации интегральной функции - регулятора узлов на качество восстановления кривых ломаными и возможности определения рациональной степени дискретизации при практических расчетах для воспроизведения изделий сложной формы. Установлено, что при достаточном количестве точек дискретизации дисперсия распределения погрешностей аппроксимации стабилизируется и увеличение этого количества на порядок незначительно повышает точность воспроизведения кривой. При этом сплайновая интерполяция значений интегральной функции давала значительно большую скорость стабилизации значений параметров распределений, что позволяет снизить количество узлов первоначальной дискретизации в 5-6 раз имея аналогичные показатели точности аппроксимации.

Выводы. Восстановление реальных плоских параметрических кривых выпуклой формы ломаными при помощи асимптотически-оптимального алгоритма интерполяции показало вполне приемлемые результаты без превышения допустимой погрешности аппроксимации в случаях достаточной степени дискретизации значений интегральной функции. Направлениями дальнейших исследований может служить исследование возможности упрощения расчетов при вычислении значений интегральной функции распределения численными методами, а также возможности использования дискретных аналогов производных в выражении этой функции.

КЛЮЧЕВЫЕ СЛОВА: интерполяция, ломаная, эквидистанта, интегрирования, плоская параметрическая кривая, погрешность

\section{ЛІТЕРАТУРА / ЛИТЕРАТУРА}

1. Asymptotically optimal disposition of tan-gent points for approximation of smooth convex surfaces by polygonal functions/ [A. A. Ligun, A. A. Shumeiko, S. P. Radzevitch, E. D. Goodman] // Computer Aided Geometric Design. 1997. - Vol. 14. - P. 533-546. DOI: 10.1016/S01678396(96)00044-1.

2. de Figueiredo L. H. Adaptive sampling of parametric curves / L. H. de Figueiredo // Graphics Gems V. - 1995. - P. 173178. DOI: $10.1016 / \mathrm{B} 978-0-12-543457-7.50032-2$.

3. Pagani L. Curvature based sampling of curves and surfaces L. Pagani, P. J. Scott // Computer Aided Geometric Design. - 2018. - Vol. 59. - P. 32-48. DOI: 10.1016/j.cagd.2017.11.004.

4. Hernández-Mederos V. Sampling points on regular parametric curves with control of their distribution / V. HernándezMederos, J. Estrada-Sarlabous // Computer Aided Geometric Design. - 2003. - Vol. 20, Issue 6. - P. 363-382. DOI: 10.1016/S0167-8396(03)00079-7.

5. A real-time interpolator for parametric curves / [W. Zhong, X. Luo, W. Chang et al.] // International Journal of Machine Tools and Manufacture. - 2018. - Vol. 125. - P. 133-145. DOI: 10.1016/j.ijmachtools.2017.11.010.

6. Bo P. Automatic fitting of conical envelopes to free-form surfaces for flank CNC machining / P. Bo, M. Bartoň, H. Pottmann // Computer-Aided Design. - 2017. Vol. 91. - P. 84-94. DOI: 10.1016/ j.cad.2017.06.006.

7. Function representation based slicer for $3 \mathrm{D}$ printing [Y. Song, Zh. Yang, Y. Liu, J. Deng] // Computer Aided Geometric Design. - 2018. - Vol. 62. - P. 276-293. DOI: 10.1016/j.cagd.2018.03.012

8. Ohrhallinger S. StretchDenoise: parametric curve reconstruction with guarantees by separating connectivity from residual uncertainty of samples / S. Ohrhallinger, M. Wimmer // Proceedings of the 26th Pacific Conference on Computer Graphics and Applications. - 2018. - P. 1-4. DOI: 10.2312/pg.20181266.

9. Cleghorn C. W. Piecewise linear approximation of ndimensional parametric curves using particle swarms C. W. Cleghorn, A. P. Engelbrecht // Swarm Intelligence.
ANTS 2012. Lecture Notes in Computer Science. Springer, Berlin, Heidelberg. - 2012. - Vol. 7461. - P. 292 299. DOI: $10.1007 / 978-3-642-32650-930$.

10. Knot locating in piecewise linear approximation [Electronic resource] / C. Ugaz, L. Han, A. Lim //arXiv preprint, arXiv 1909.03112. - 2019. - 13 p. - Access mode: https://arxiv.org/abs/1909.03112

11. Berjón D. Optimal piecewise linear function approximation for GPU-based applications / D. Berjón, G. Gallego, C. Cuevas et al. // IEEE Transactions on Cybernetics. 2016. - Vol. 46 (11). - P. 2584-2595. DOI: 10.1109/TCYB.2015.2482365.

12. Polygonal curve evolutions for planar shape modeling and analysis / [A. G. Belyaev, E. V. Anoshkina, S. Yoshizawa, M. Yano] // International Journal of Shape Modeling. 1999. - Vol. 05, No. 02. - P. 195-217. DOI: $10.1142 / \mathrm{S} 0218654399000174$

13. Langer T. Asymptotic analysis of discrete normals and curvatures of polylines / T. Langer, A. G. Belyaev, H.-P. Seidel // SCCG '05: Proceedings of the 21st Spring Conference on Computer Graphics. - 2005. - P. 229-232. DOI: $10.1145 / 1090122.1090160$.

14. Approximation of curves with piecewise constant or piecewise linear functions [Electronic resource] / F. Gournay, J. Kahn, L. Lebrat // HAL Id hal-02284549. - 2019.- 17 p. Access mode: https://arxiv.org/pdf/1909.04582.pdf

15. LiMITS: An effective approach for trajectory simplification [Electronic resource] / Y. Han, H. Samet // arXiv pre-print, arXiv:2010.08622v1. - 2020 - 13 p. - Access mode: https://arxiv.org/abs/2010.08622v1

16. Fuhr R. D. Monotone linear rational spline interpolation. / R. D. Fuhr, M. Kallay // Computer Aided Geometric Design. - 1992. - Vol. 9, Issue 4. - P. 313-319. DOI:10.1016/0167-8396(92)90038-Q.

17. Epperson J.F. An introduction to numerical methods and analysis / J. F. Epperson. - New Jersey : Wiley, 2013. $615 \mathrm{p}$.

18. Oja P. Low degree rational spline interpolation / P. Oja // BIT Numerical Mathematics. - 1997. - Vol.37, Issue 4. P. 909. DOI:10.1007/BF02510359. 